\title{
EVALUATION OF ANTIOXIDANT POTENTIAL AND REDUCING POWER OF CALLUS INDUCED FROM LEAVES OF ASYSTASIA GANGETICA (L.) T.ANDERSON
}

\author{
T. G. UMESH* , ABHIRAMI DILKALAL \\ Department of Botany Bangalore University Jnanabharathi Campus Bangalore Karnataka 560056 \\ Email: drtgumesh@gmail.com
}

https://innovareacademics.in/journals/index.php/ijpps/article/view/1981

\begin{abstract}
Objective: To evaluate the bioactive molecules and antioxidant potential of callus induced from leaves of Asystasia gangetica.
\end{abstract}

Methods: In this report, the leaves of A.gangetica (AG) were incubated with Murashige and Skoog (MS) medium supplemented with combinations of auxins and cytokinins for callus induction. The qualitative estimation of bioactive molecules like flavonoids, phenolics, tannins and their antioxidant potential were investigated. The ability of radical scavenging activity and reducing power of methanolic, ethanolic and aqueous extract using DPPH, FRAP and Phopshomlybdate assay were carried out.

Results: Callus was induced on MS medium supplemented with various concentration and combination of auxins and cytokinins.Maximum percentage of callusing was seen on media supplemented with 2,4-Dichlorophenoxyaceticacid 5mg/L or combination of Kinetin $2 \mathrm{mg} / \mathrm{L}$ and $2 \mathrm{mg} / \mathrm{L}$ Napthaleneaceticacid.The total phenolic content, flavonoids and tannins in callus were estimated in various solvents. Further, the callus showed the FRAP values of $17.67 \pm 0.0,17.30 \pm 1.830$ and $23.81 \pm 0.945 \mu \mathrm{g} \mathrm{AAE} \mathrm{/} \mathrm{mg} \mathrm{extract} \mathrm{for} \mathrm{methanolic,} \mathrm{ethanolic} \mathrm{and} \mathrm{aqueous} \mathrm{extract} \mathrm{respectively.}$ Methanolic extract showed highest DPPH scavenging activity and reducing abilty.

Conclusion: A.gangetica callus had substantial amount of bioactive molecules exhibiting potent antioxidant activity and reducing ability. Development of appropriate strategies for enhancing the bioactive molecules in callus could have far-reaching implications for isolation of novel antioxidant molecules for human health.

Keywords: Asystasia, Callus, Phenolics, Tannins, FRAP, Reducing power, DPPH

\section{Correction for incorrect citation and mismatch of references}

In the article "EVALUATION OF ANTIOXIDANT POTENTIAL AND REDUCING POWER OF CALLUS INDUCED FROM LEAVES OF ASYSTASIA GANGETICA (L.) T. ANDERSON". International Journal of Pharmacy and Pharmaceutical Sciences, Vol. 6, no. 8, Aug. 2014, pp. 532-8, references were mismatching with the reference cited in the text. Reference 28 was misquoted inadvertently. The correct citation for ref (28) is Murashige T, Skoog F. A revised medium for rapid growth and bioassays with tobacco tissue cultures. Physiol Plant 1962;15:473-9. For the remaining references, the number changes accordingly. The correct references are appended in the attached file. We regret to readers for leading to confusion.

The correct references are cited below.

\section{REFERENCES}

1. Ramachandra RS, Ravishankar GA. Plant cell cultures: chemical factories of secondary metabolites. J Biotech Adv 2002;20:101-53.

2. Speroni E, Scartezzini P. Review on some plants of Indian traditional medicine with antioxidant activity. J Ethnopharm 2000;71:23-43.

3. Matkowski A. Plant in vitro culture for the production of antioxidants-a review. J Biotech Adv 2008;26:548-60.

4. Ali SS, Kasoju N, Luthra A, Singh A, Sharanabasava H, Sahu A, et al. Indian medicinal herbs as sources of antioxidants. J Food Res Int 2008;41:115.

5. Krishnaiah D, Sarbatly R, Nithyanandam R. A review of the antioxidant potential of medicinal plant species. J Food Bioproducts Proc 2011;89:217-33.

6. Winston JC. Health-promoting properties of common herbs. Am J Clin Nutr 1999;70:491-9.

7. Tillo SK, Pande VB, Rasala TM, Kale VV. Asystasia gangetica: review on multipotential application. Int Res J Pharm 2012;3:18-20.

8. Devi Prasad AG, Shyma TB, Raghavendra MP. Plants used by the tribes for the treatment of digestive system disorders in wayanad district, Kerala. J Appl Pharm Sci 2013;3:171-5.

9. Akah PA, Ezike AC, Nwafor SV, Okoli CO, Enwerem NM. Evaluation of the anti-asthmatic property of Asystasia gangetica leaf extracts. J Ethnopharm 2003;89:25-36.

10. Ezike AC, Akah PA, Okoli CO. Bronchospasmolytic activity of the extract and fractions of Asystasia gangetica leaves. Int J Appl Res Nat Prod 2008;1:8-12.

11. Doffodil ED, Packia LM, Pon Esakki D, Mohan VR. Pharmacochemical characterization and antibacterial activity of Asystasia gangetica (L). T. AND. J Har Res 2013;2:112-20.

12. Hamid AA, Aiyelaagbe 00, Ahmed RN, Usman LA, Adebayo SA. Preliminary phytochemistry, Antibacterial and Antifungal Properties of extracts of Asystasia gangetica Linn T. Anderson grown in Nigeria. J Adv Appl Sci Res 2011;2:219-26.

13. Pradeep Kumar R, Sujatha D, Mohamed Saleem TS, Madhusudhana Chetty C, Ranganayakulu D. Potential hypoglycemic and hypolipidemic effect of Morus indica and Asystasia gangetica in alloxan-induced diabetes mellitus. Int J Pharm Sci 2010;1:51-6.

14. Pradeep Kumar R, Sujatha D, Mohamed Saleem TS, Madhusudhana Chetty C, Ranganayakulu D. Potential antidiabetic and antioxidant activities of Morus indica and Asystasia gangetica in alloxan-induced diabetes mellitus. J Exp Pharm 2010;2:29-36.

15. Gopal TK, Megha G, Chamundeeshwari D, Umamaheshwara R. Phytochemical and pharmacological studies on whole plant Asystasia gangetica. Indian J Res Pharm Biotech 2013;1:365-70.

16. Ramesar S, Baijnath H, Govender T, Mackraj I. Angiotensin I-converting enzyme inhibitor activity of nutritive plants in kwa zulu-natal. J Med Food 2008;11:331-6. 
17. Stewart P, Boonsiri P, Puthong S, Rojpibulstit P. Antioxidant activity and ultrastructural changes in gastric cancer cell lines induced by Northeastern Thai edible folk plant extracts. J BMC Comp Alt Med 2013;13:60.

18. Odhav B, Beekrum S, Akula U, Baijnath H. Preliminary assessment of the nutritional value of traditional leafy vegetables in KwaZulu-Natal, South Africa. J Food Comp Anal 2007;20:430-5.

19. Yang R, Keding GB. Nutritional contributions of important African indigenous Vegetables. IN African Indigenous Vegetables in Urban Agriculture. Charlie MS, Margaret WP. Axel WD, editors. London: Earthscan publishers; 2009. p. 105-45.

20. Orech FO, Friis H, Estambale BA, Ogoye-Ndegwa C, Aagaard-Hansen J. Food safety and food security in relation to consumption of indigenous leafy vegetables among the luo in Western Kenya. J Nutr Eco Food Res 2013;1:240-5.

21. Jiju V, Megha Gorantla, Chamundeeswari D. Evaluation of anthelmintic activity of methanolic extract of Asystasia gangeticum. Int J Pharm Life Sci 2013;4:2727-30.

22. Kanchanapoom T, Ruchirawat S. Megastigmane glucoside from Asystasia gangetica (L.) T. Anderson. J Nat Med 2007;61:430-3.

23. Subramanian SS, Nair AGR. Flavonoids of Thunbergia grandiflora and Asystasia travancorica. J Curr Sci 1971;40:404.

24. Worawittayanon P, Ruadreo J, Disadee W, Sahakitpichan P, Sitthimonchai S, Thasana N, et al. Iridoid and flavone glycosides from Asystasia gangetica subsp. Micrantha and Asystasia salicifolia and their antioxidant activities. J Biochem Syst Eco 2012;40:38-42.

25. Aysel S, Sevan D. Evaluation of seasonal antioxidant activity and total phenolic compounds in stems and leaves of some almond (Prunus amygdalus L.) varieties. J Biol Res 2014;47:9.

26. Gulluce M, Sokmen M, Daferera D, Agar G, Ozkan H, Kartal N, et al. In vitro antibacterial, antifungal, and antioxidant activities of the essential oil and methanol extracts of herbal parts and callus cultures of Satureja hortensis L. J Agric Food Chem 2003;51:3958-65.

27. Frankel EN, Meyer ES. The problems of using one-dimensional methods to evaluate multifunctional food and biological antioxidants. J Sci Food Agric 2000;80:1925-41.

28. Murashige T, Skoog F. A revised medium for rapid growth and bioassays with tobacco tissue cultures. Physiol Plant 1962;15:473-97.

29. Harborne JB. Phytochemical methods: a guide to modern techniques of plant analysis. $3^{\text {rd }}$ ed. London, New York: Chapman and Hall; 1998.

30. Singleton VL, Orthofer R, Lamuela Raventos RM. Analysis of total phenols and other oxidation substrates and antioxidants by means of folinciocalteu reagent. J Methods Enzymol 1999;299:152-78.

31. Chang C, Yang M, Wen H, Chern J. Estimation of total flavonoid content in Propolis by two complementary colorimetric methods. J Food Drug Anal 2002;10:178-82.

32. Sun B, Richardo-Da-Silvia JM, Spranger I. Critical factors of vanillin assay for catechins and proanthocyanidins. J Agric Food Chem 1998;46:4267-74.

33. Sharma OP, Bhat TK. DPPH antioxidant assay revisited. J Food Chem 2009;113:1202-5.

34. Prieto P, Pineda M, Aguilar M. Spectrophotometric quantitation of antioxidant capacity through the formation of a phosphomolybdenum complex: specific application to the determination of vitamin E. J Anal Biochem 1999;269:337-41.

35. Benzie IFF, Strain JJ. The ferric reducing ability of plasma (FRAP) as a measure of antioxidant power: the FRAP assay. J Anal Biochem 1996;239:70-6.

36. Oyaizu M. Studies on products of browning reactions: antioxidative activities of products of browning reaction prepared from glucosamine. Japan J Nut 1986;44:307-15.

37. Rrice Evans CA, Miller NJ, Paganga G. Antioxidant properties of phenolic compounds. J Trends Plant Sci 1997;2:152-9.

38. Zengin G, Aktumsek A, Guler GO, Cakmak YS, Yildiztugay E. Antioxidant properties of methanolic extract and fatty acid composition of Centaurea urvillei DC. subsp. hayekiana Wagenitz. J Res Nat Prod 2011;5:123-32.

39. Mahalakshmi R, Eganathan P, Ajaykumar P. Salicylic acid elicitation on the production of secondary metabolite by cell Cultures of Jatropha curcas L. Int J Pharm Pharm Sci 2013;5:655-9.

40. White PR. Potentially unlimited growth of excised plant callus in an artificial nutrient. Am J Bot 1939;26:59-64.

41. Skoog F, Miller CO. Chemical regulation of growth and organ formation in plant tissues cultured in vitro. J Symp Soc Exp Biol 1957;11:118-30.

42. Bourgaud F, Gravot A, Milesi S, Gontier E. Production of secondary plant metabolites: a historical perspective. J Plant Sci 2001;161:839-51.

43. Xie D, Hong Y. In vitro regeneration of Acacia mangium via organogenesis. J Plant Cell Tissue Organ Culture 2001;66:167-73.

44. Sunita K, Sonia B, Nitin C, Amandeep K. Synergistic effects of 2,4-D and cytokinins on callus culture establishment in rare medicinal plantGymnema sylvestre. Int J Sci Eng Res 2014;5:213-8.

45. Sen MK, Nasrin S, Rahman S, Jamal AHM. In vitro callus induction and plantlet regeneration of Achyranthes aspera L, a high-value medicinal plant. Asian Pacific J Tro Bio 2014;4:40-6.

46. Tamilselvan V, Rajeshwari M. Impact of growth regulators on callus production of Asystasia gangetica (L) T. Anderson. J Adv Appl Sci Res 2014;5:328-33.

47. Kahkonen MP, Hopia AI, Vuorela HJ, Rauha JP, Pihlaja K, Kujala TS, et al. Antioxidant activity of plant extracts containing phenolic compounds. J Agric Food Chem 1999;47:3954-62.

48. Iwase A, Mitsuda N, Koyama T, Hiratsu K, Kojima M, Arai T, et al. The AP2/ERF transcription factor WIND1 controls cell dedifferentiation in Arabidopsis. J Curr Biol 2011;21:508-14.

49. Shinde AN, Malpathak N, Fulzele DP. Determination of isoflavone content and antioxidant activity in Psoralea corylifolia L. callus cultures. J Food Chem 2010;118:128-32.

50. Amid A, Johan NN, Jamal P, Mohd ZWN. Observation of antioxidant activity of leaves, callus and suspension culture of Justicia gendarusa. Afr J Biotech 2011;10:18653-6.

51. Wang J, Xuan X, Wang Q, Li X, Zhang L, Li J. Accumulation of flavonoids and antioxidant activity of Stellera chamaejasme by an efficient callus culture. J Hort Environ Biotech 2013;54:441-9.

52. Matkowski A. In vitro isoflavonoid production in callus from different organs of Pueraria lobata (Wild) Ohwi. J Plant Phys 2004;161:343-6.

53. Salunkhe DK, Chavan JK, Kadam SS. Dietary tannins: consequences and remedies. J Boca Raton FL CRC Press Inc; 1989.

54. Amarowicz R. Tannins: the new natural antioxidants? Eur J Lipid Sci Technol 2007;109:549-51.

55. Villano D, Fernandez Pachon MS, Moya ML, Troncoso AM, Garcia Parilla MC. Radical scavenging ability of phenolic compounds towards DPPH free radical. J Talanta 2007;71:230-5.

56. Bhagya KR, Chandrashekar KR. Evaluation of plant and callus extracts of Justicia gendarussa Burm. F. for phytochemicals and antioxidant activity. Int J Pharm Pharm Sci 2013;5:82-5.

57. Saradha M, Ranjitham P, Paulsamy S. Evaluation of in vitro antioxidant properties of callus cultures of an endangered medicinal tree species, Hildegardia populifolia (roxb.) schott and endl. Int J Pharm Sci Res 2014;5:839-48.

58. Schleisier K, Harwat M, Bohm V, Bitsch R. Assessment of antioxidant activity by using different in vitro methods. J Free Rad Res 2002;36:17787.

59. Siddhuraju P, Mohan PS, Becker K. Studies on the antioxidant activity of Indian laburnum (Casssia fistula L):a preliminary assesment of crude extracts from stem bark, leaves, flowers and fruit pulp. J Food Chem 2002;79:61-7. 
60. Renuka D, Amit S, Malpathak N. Phytochemical composition and antioxidant potential of Ruta graveolens L. In vitro culture lines. J Botany 2012. DOI:10.1155/2012/685427

61. Shinde AN, Malpathak N, Fulzele D. Determination of isoflavone content and antioxidant activity in Psoralea corylifolia L. callus cultures. J Food Chem 2010;118:128-32. 